\title{
DEBIUTY
}

EWELINA LIGĘZA

Uniwersytet Kardynała Stefana Wyszyńskiego

Forum Pedagogiczne

Warszawa

\section{HANDEL LUDŹMI - CHARAKTERYSTYKA I SKALA ZJAWISKA}

Streszczenie: Artykuł prezentuje podstawowe zagadnienia dotyczące handlu ludźmi. Charakteryzuje ofiary tego przestępstwa (dzieci i kobiety), metody działania sprawców, skalę zjawiska i prawne aspekty walki z tym problemem. W artykule przytoczone zostały także przykładowe sytuacje handlu ludźmi.

Słowa kluczowe: handel ludźmi, praca przymusowa, handel dziećmi, ofiara, przestępstwo

\section{Podstawowe zagadnienia terminologiczne}

Handel ludźmi to zjawisko społeczne oraz polityczne, które należy rozpatrywać w kategorii zbrodni (jest to tzw. kwalifikowane przestępstwo). Jego geneza sięga starożytności - praktyk niewolniczych, czyli handlu służbą domową. Również w czasach starożytnych wojen jedną $\mathrm{z}$ oznak zwycięstwa było zamykanie $\mathrm{w}$ niewoli sprawnych do pracy ludzi z grupy przegranej.

Współcześnie problem ten zalicza się do grupy przestępstw międzynarodowych, a zatem jest ścigany i karany na podstawie umów między poszczególnymi państwami (DawidOlczyk, Dośpiał 2004).

Aktualnie przyjmuje się, że: „Handel ludźmi oznacza werbowanie, transport, przekazywanie, przechowywanie lub przyjmowanie osób z zastosowaniem gróźb lub użyciem siły lub też z wykorzystaniem innej formy przymusu, uprowadzenia, oszustwa, wprowadzenia w błąd, nadużycia władzy lub wykorzystania słabości, wręczenia lub przyjęcia płatności lub korzyści dla uzyskania zgody osoby mającej kontrolę nad inną osobą w celu wykorzystania. Wykorzystanie obejmuje, jako minimum, wykorzystanie prostytucji innych osób lub inne formy wykorzystania seksualnego, pracę lub usługi o charakterze przymusowym, niewolnictwo lub praktyki podobne do niewolnictwa, zniewolenie albo usunięcie organów" (Protokół o zapobieganiu, zwalczaniu oraz karaniu za handel ludźmi, w szczególności kobietami i dziećmi, uzupełniający Konwencję Narodów Zjednoczonych przeciwko międzynarodowej przestępczości zorganizowanej $z$ dnia 15 listopada 2000 r.).

Przestępstwem jest „zawinione zachowanie się człowieka, zabronione przez ustawę pod groźbą kary jako społecznie niebezpieczne" (Encyklopedia popularna PWN 1982 s.636). Z pojęciem tym łączy się zagadnienie ofiary przestępstwa. Takimi ofiarami określa się „osoby, które indywidualnie lub zbiorowo poniosły uszczerbek na zdrowiu fizycznym lub psychicznym, doznały zaburzeń emocjonalnych, strat materialnych lub istotnego 
naruszenia swoich podstawowych praw w wyniku działania lub zaniechania będącego naruszeniem ustaw karnych, obowiązujących w państwach członkowskich, w tym również ustaw dotyczących przestępczego nadużywania władzy" (Rezolucja Zgromadzenia Ogólnego ONZ 4o/34 z dnia 29 listopada 1985 r.). Natomiast osobę sprawcy przestępstwa, czyli przestępcę, określić można jako tego, kto osobiście popełnia dane przestępstwo (Kalina-Prasznic 2004).

Do podstawowych form handlu ludźmi zalicza się:

- handel dziećmi;

- handel kobietami;

- pracę przymusową, żebractwo;

- handel narządami.

Grupy będące najczęstszymi ofiarami handlu ludźmi to kobiety i dzieci. W Polsce problem ten w znacznej mierze dotyczy mniejszości narodowych, ale jest on na tyle skomplikowany i poważny, że trudno jest wskazać jego bezpośrednie wymiary.

Jedną z głównych przyczyn handlu ludźmi jest osiągnięcie dochodów przez sprawcę poprzez nielegalny obrót towarów czy przepływ ludzi.

Współcześnie zjawisko to jest formą niewolnictwa. Problem ten godzi w wartości, które powinny być chronione oraz narusza prawa człowieka, dlatego państwom zaleca się penalizację tego przestępstwa, czyli traktowanie go jako poważniejsze. Człowiek jest nade wszystko osobą, podmiotem, który nie powinien być przedmiotem zysku.

\section{Rozmiary zjawiska}

Statystyczne rozmiary zjawiska są szacunkowe, ponieważ wielu przestępstw nie udaje się odkryć i nie są odnotowane przez organy ścigania.

W Polsce, jako kraju pochodzenia ofiar handlu ludźmi, grupy przestępcze koncentrują się wzdłuż zachodniej granicy z Niemcami (Poznań, Szczecin, Gorzów Wielkopolski, Słubice, Świnoujście, Zgorzelec). Jako kraj tranzytowy przez Polskę przekazywane są ofiary handlu ludźmi z takich krajów jak: Mołdawia, Łotwa, Litwa, gdzie punktem docelowym są w szczególności Niemcy, gdyż Polacy prowadzą swoje grupy przestępcze w porozumieniu z niemieckimi agencjami towarzyskimi. Natomiast w Polsce najliczniejszymi ofiarami handlu ludźmi są obywatele Ukrainy, Bułgarii, Rumunii, Białorusi, a także pozostałych państw tzw. „byłego bloku wschodniego” (Karsznicki 2010).

Trudno jest przytoczyć dokładne liczby związane z tym przestępstwem, niemniej jednak ogólną liczbę dla ofiar handlu ludźmi w Polsce, jako kraju pochodzenia, tranzytowym i docelowym, podaje się w przybliżeniu do około 15000 ofiar rocznie, przy czym dane Prokuratury Krajowej w latach 1995-2005 wskazują 1708 ofiar (Wiśniewski 2007). W statystykach tych zauważalna jest poważna rozbieżność, co dostrzec można również w liczbach podawanych przez samą Unię Europejską czy agencje amerykańskie zwalczające problem handlu ludźmi.

Jeśli mamy na uwadze dzieci jako ofiary handlu ludźmi, to najwięcej z nich pochodzi z Rosji, Ukrainy, Rumunii, Białorusi, Bułgarii, Mołdawii, Albanii, Słowacji, Litwy, Łotwy i Estonii. Krajami docelowymi dla tych ofiar są: Grecja, Włochy, Hiszpania, Francja, Szwajcaria, Austria, Niemcy, Belgia, Holandia, Dania, Wielka Brytania, Irlandia, Norwegia, Szwecja, Finlandia. Natomiast przepływ dzieci następuje przez takie kraje jak: Polska, 
Czechy, Węgry, Słowenia, Serbia, Chorwacja, Bośnia i Hercegowina, Czarnogóra. W samej Europie Południowo-Wschodniej, w latach 2000-2004, Międzynarodowa Organizacja ds. Migracji odnotowała 6256 ofiar handlu ludźmi. W danych tych uwzględniono najwięcej dziewczynek w wieku 15-18 lat, sprzedawanych w celach seksualnych, natomiast dzieci (zarówno dziewczynki, jak i chłopcy), poniżej 13 roku życia sprzedawane były w celach żebraczych, pracy przymusowej lub do celów sprzedaży organów (Problem handlu dziećmi w Polsce i na świecie 2008).

Liczba przestępstw stwierdzonych, dotycząca handlu ludźmi wynosiła: w roku 2010 39 przypadków, w roku 2011 - 427 przypadków, a w roku 2012 - 61 przypadków (Sobczyk, Przybysławska 2013).

W statystykach światowych podanych przez Biuro Narodów Zjednoczonych do spraw Narkotyków i Przestępczości (UNODC) 59\% ofiar handlu ludźmi stanowią kobiety, 17\% dziewczynki, 14\% mężczyźni, a 10\% chłopcy (dane na rok 2009). Najczęstszym celem handlu ludźmi na świecie są przestępstwa seksualne - 58\%, następnie praca przymusowa - 36\%, usuwanie narządów - 0,2\% i pozostałe formy handlu stanowiące 6\% (dane na rok 2010). W samej Ameryce Północnej i Południowej w 73\% ofiarami handlu ludźmi są osoby dorosłe, zaś w $27 \%$ są nimi dzieci. Również na tych kontynentach ofiary wykorzystywane są przede wszystkim do przestępstw seksualnych - 51\%, oraz pracy przymusowej - $41 \%$, zaś pozostałe formy handlu stanowią 5\% (dane na lata 2007-2010). We wschodniej Azji oraz krajach Pacyfiku najczęstsza formą handlu ludźmi jest praca przymusowa - 47\%, następnie przestępstwa seksualne - 44\%, i pozostałe formy - 9\% (dane na lata 2007-2010). W Afryce najwięcej ofiar handlu ludźmi wykorzystywanych jest do pracy przymusowej - 49\%, w dalszej kolejności do przestępstw seksualnych - 36\%, a w 14\% są to inne formy handlu ludźmi (dane na lata 2007-2010) (Kangaspunta i in. 2012).

Wszystkie statystyki ukazują, że najczęstszymi ofiarami handlu ludźmi na świecie są kobiety oraz młode dziewczynki. W każdej sytuacji handlu ludźmi należy pamiętać o tym, że życie ludzkie jest podstawową wartością, zatem każda jednostka ma swoją godność i wolność. Nie można więc nikogo pozbawić tej wolności np. poprzez niewolnictwo. Każdy, a w szczególności dziecko, ma prawo do nauki, zatem ciężka praca fizyczna od najmłodszych lat nie jest odpowiednia dla wieku rozwojowego. W życiu dorosłym jednostka powinna mieć zapewnione godziwe warunki pracy, odpowiednie świadczenia zdrowotne, a nie doświadczać wykorzystywania. Nigdy również nie powinno stosować się różnych form dyskryminacji, tu w szczególności ze względu na kolor skóry, płeć, pochodzenie, czy religię. Nikt też nie może być traktowany w sposób tak nieludzki jak np. bicie czy poniżanie, które szczególnie w zjawisku handlu ludźmi kojarzone jest z torturowaniem. I choć prawa człowieka łamane są codziennie, pod wieloma różnymi aspektami, to państwo w sposób szczególny powinno dbać o przestrzeganie tych praw. „Jedną z najdrastyczniejszych form łamania praw człowieka jest handel ludźmi” (Dośpiał, Garnier 2007).

\section{Metody działania sprawców}

W działaniach sprawcy wobec ofiary zauważyć można charakterystyczne metody, o wysokim stopniu skomplikowania, tak dokładnie przygotowywane, iż ofierze bardzo trudno jest niekiedy zorientować się, w czym bierze ona udział. 
Całościowa droga, którą przechodzi ofiara, rozpoczyna się od etapu rekrutacji. W kraju pochodzenia ofiary pojawiać się mogą oferty matrymonialne lub ofiara wchodzi w szybko się rozwijający związek emocjonalny - celem jest zauroczenie się, a nawet zakochanie ofiary w sprawcy. Należy tu zaznaczyć, że osoba sprawcy jest pod tym względem specjalnie przygotowywana od strony psychologicznej, a w tym relacji międzyosobowych. Sprawca tak sprawnie manipuluje ofiarą, iż po dłuższym czasie znajomości proponuje jej wyjazd do rzekomej rodziny w oddalonym kraju. Ofiara, która ufa sprawcy i nie wyobraża sobie bez niego życia, postanawia wyjechać, ale niestety, jak okazuje się później - nie ma już powrotu, gdyż sprawca odbiera jej wszelkie dokumenty i zmienia do niej stosunek, zachowując się agresywnie i zagrażająco. Etap rekrutacji ofiary może przebiegać również poprzez prywatne kontakty. Zdarza się także, iż ofiary są uprowadzane. Sam wybór ofiary dokonuje się poprzez analizowanie jej płci, wieku, sytuacji materialnej czy rodzinnej.

Może dojść do sytuacji porwania, w którym uprowadza się dziecko ofiary i zmusza ją do pracy, szantażując krzywdą dziecka. Gdy ofiara ma więcej niż jedno dziecko, wtedy szantażować można zarówno matkę, jak i dziecko, zagrażając śmiercią życiu jej kolejnego dziecku

Innymi kryteriami doboru ofiary są np. jej plany przyszłościowe i ambicje. Gdy sprawca wybada takie informacje, będzie dobrze wiedział, jaką pracę należy zaoferować danej osobie, by była nią ona zainteresowana. Przestępca specjalnie wprowadza swoją ofiarę w błąd, stosuje wobec niej podstęp i wykorzystuje jej słabości, by stać się w jej oczach osobą odpowiednio wykwalifikowaną i poważaną (Dawid-Olczyk, Dośpiał 2004).

Po wybraniu ofiary w dalszej kolejności następuje przekroczenie granicy, które może być legalne (poprzez tzw. zieloną granicę, czyli miejsce słabo chronione na granicy państwa, pokryte znaczną roślinnością) lub też nielegalne (poprzez przejście graniczne, w ukryciu lub np. ze sfałszowanymi dokumentami). Może dojść również do legalizacji pobytu poprzez fikcyjne małżeństwo, specjalną wizę zezwalającą na pracę lub też wizę studencką, która umożliwia pobyt $\mathrm{w}$ danym kraju przez kilka lat.

Na terenie obcego państwa następuje przejęcie kontroli nad ofiarą, np. zmuszenie ofiary do posługiwania się cudzymi dokumentami. Następnie sprawca znacznie uzależnia ofiarę od siebie. Jest to uzależnienie finansowe - gdyż odbiera jej wszystkie środki materialne; emocjonalne - ponieważ pozbawia ją kontaktu z bliskimi. Często dochodzi również do podawania ofierze różnych środków psychoaktywnych, mające na celu zmianę jej świadomości. Podczas tych wszystkich zachowań sprawca tworzy pozory swojej bezkarności. $\mathrm{W}$ dalszej kolejności stosuje wobec niej przemoc fizyczną oraz psychiczną. Przemoc fizyczna może przybierać postać bicia, pozbawienia wolności czy gwałcenia. Natomiast przemoc psychiczna to wszelkiego rodzaju groźby, zastraszania i szantaże w stosunku do ofiary. Długotrwałe stosowanie przemocy oraz pozbawienie ofiary wiarygodności powstrzymuje ją przed składaniem zeznań (Dawid-Olczyk, Dośpiał 2004), mimo iż każdy z wymienionych wcześniej etapów stanowi poważne przestępstwo w udziale handlu ludźmi.

\section{Charakterystyka ofiar przestępstwa handlu ludźmi}

Pojęcie handlu ludźmi, choć zawiera w swej nazwie ogólną grupę ofiar tego przestępstwa, to $\mathrm{w}$ wielu aktach prawnych, dotyczących tego zjawiska, ujmuje szczególnie dwie grupy narażone na to przestępstwo - kobiety oraz dzieci. Protokół o zapobieganiu, zwalczaniu 
oraz karaniu handlu ludźmi, w szczególności kobietami i dziećmi określa międzynarodowe normy prawne, charakterystyczne dla tego przestępstwa, w tym m.in. art. 3 protokołu definiuje dziecko jako osobę która nie ukończyła 18 roku życia (Protokół o zapobieganiu, zwalczaniu oraz karaniu za handel ludźmi, w szczególności kobietami i dziećmi, uzupetniający Konwencję Narodów Zjednoczonych przeciwko międzynarodowej przestępczości zorganizowane $z$ dnia 15 listopada 200o).

Profile małoletnich ofiar handlu ludźmi przedstawiają się następująco:

- Nastolatkowie, obojga płci, powyżej 15 roku życia, wykorzystywani do pracy fizycznej (praktyki niewolnicze) oraz pracy w seksprzemyśle. Najczęściej są oni obywatelami Azji Wschodniej oraz krajów postradzieckich. Wywodzący się z ubogich dzielnic i rodzin, podejmują decyzję o migracji w celach materialnych. Najczęściej są oni werbowani poprzez nieuczciwe ogłoszenia o pracy.

- Małoletni w różnym wieku; sprzedawani do kradzieży, żebractwa czy pracy w charakterze pomocy domowej. W ich sytuacji to często rodzice fundują im taki los, chcąc z poprawy sytuacji materialnej rodziny. Taka forma charakterystyczna jest dla obywateli Rumunii i Mołdawii; dzieci poniżej 5 roku życia sprzedawane do adopcji. W tym przypadku tzw. agenci adopcyjni handlujący dziećmi otrzymują zamówienia na konkretne „typy” dzieci (płeć, wiek, kolor oczu, włosów, skóry). Agenci poszukują zatem takich dzieci, często poprzez znajomości, które znajdują się w domach dziecka, domach samotnych matek czy szpitalach położniczych (Morawska 2007).

Profile ofiar pracy przymusowej stworzone na podstawie polskich badań określają, iż najczęściej są nimi ludzie w młodym oraz średnim wieku, zarówno kobiety, jak i mężczyźni. Wiek ofiar pracy przymusowej mieści się w przedziale od 18 do 60 lat.

W żebractwie dominują przeważnie młode kobiety z dziećmi, a mężczyźni, jako ofiary dominowali na plantacjach rolnych we Włoszech. Natomiast do pracy w Stoczni Gdańskiej zmuszani byli młodzi mężczyźni - obywatele Bangladeszu. Obecnie nadal wśród ofiar pracy przymusowej w Polsce dominują obywatele państw Europy Wschodniej - w znacznym stopniu mieszkańcy Ukrainy. Ponadto wiele ofiar pochodzi z Azji (tu w szczególności z Wietnamu i Bangladeszu).

Dla państw graniczących z Polską kraj ten jest atrakcyjny pod względem zarobkowym. Polska stanowi również miejsce, w którym cudzoziemcy mogą wzbogacić się na tyle, by następnie łatwiej przekroczyć granice innych państw europejskich.

Ofiary handlu ludźmi, które uczestniczą w rekrutacji do tego celu, opuszczając swój dom rodzinny, sprzedają całe swoje majątki (jak np. w Bangladeszu), by uiścić odpowiednie opłaty, które sugeruje im sprawca. Zarówno Polacy, jak i cudzoziemcy - przybywający do Polski w celach pracy nie znają języka kraju, do którego się udają (Lasocik, Wieczorek 2010). Problem związany $z$ ofiarami pracy przymusowej polega na tym, iż w znacznym stopniu świadczą one pracę nielegalną, stąd też obawiają się sankcji karnych, jakie może wymierzyć im państwo, w którym przebywają (Lasocik, Wieczorek 2010).

Fundacja La Strada, zajmująca się zwalczaniem handlu ludźmi oraz niewolnictwa, a także pomocom ofiarom tego przestępstwa, na podstawie badań z lat 2004-2006 określiła profil kobiet - ofiar handlu ludźmi. Według tych danych najwięcej ofiar przestępstwa było w wieku 21-25 lat (30 kobiet), zaś najmłodsza z nich miała 13 lat, a najstarsza 52 lata. Z pomocy fundacji najczęściej korzystały Polki (41 kobiet), zaś w grupie cudzoziemek największy odsetek stanowiły Ukrainki (12 kobiet), Mołdawianki (9 kobiet) i Bułgarki (4 
kobiety). W w sprawach karnych najliczniejszą grupę ofiar stanowiły Białorusinki. Wśród tych pokrzywdzonych 30 kobiet legitymowało się wykształceniem średnim, 23 wykształceniem podstawowym, zaś najliczniejszą grupą były ofiary z wykształceniem zawodowym. Większość kobiet nie posiadała dzieci. Najwięcej z nich pracowało w prostytucji (3o kobiet), natomiast 8 kobiet zatrudnionych zostało do żebractwa. W rodzinach pochodzenia kobiet panowało ubóstwo oraz przejawy patologii tj. przemoc i alkoholizm, co skłoniło ofiary do podjęcia pracy w innym kraju. Ofiary handlu ludźmi najczęściej zgłaszane były do fundacji poprzez policję, organizacje pozarządowe lub też konsulaty RP (Karsznicki 2010).

\section{Zagadnienia szczegółowe handlu ludźmi}

\section{Handel dziećmi}

Handel dziećmi to zjawisko, które obecnie przybiera coraz nowsze formy w porównaniu $\mathrm{z}$ handlem osobami dorosłymi (Morawska 2006). Gwarancję ochrony ich praw w tym zakresie stanowi Konwencja o prawach dziecka z dnia 20 listopada 1989 r. Jednym z jej podstawowych postanowień jest zakaz zrywania więzi dziecka z osobami, które sprawują nad nim opiekę (Sitarz 2007). Również w konwencji tej szczególnie podkreślone zostaje to, iż „dzieci mają prawo do szczególnej troski i pomocy [...], wychowywać się w środowisku rodzinnym, w atmosferze szczęścia, miłości i zrozumienia [...], w duchu pokoju, godności, tolerancji, wolności, równości i solidarności" (Konwencja o prawach dziecka przyjęta przez Zgromadzenie Ogólne Narodów Zjednoczonych dnia 20 listopada 1989 r.). Zatem odpowiedzialność za niepełnoletnie dzieci ponoszą rodzice, którzy powinni zapewnić dziecku zaspokojenie potrzeb.

Do podstawowych form handlu dziećmi zalicza się:

- seksbiznes dziecięcy (zmuszanie do prostytucji i rozpowszechnianie pornografii);

- nielegalne adopcje;

- zmuszanie do żebractwa;

- zmuszanie do popełniania przestępstw;

- sprzedaż w celu handlu organami (Problem handlu dziećmi w Polsce i na świecie 2008).

Czynnikami, które powodują, że dzieci stają się ofiarami handlu, są m.in. brak opieki, niestabilna sytuacja rodzinna, patologia w rodzinie, przemoc fizyczna i psychiczna, wykorzystywanie seksualne, ucieczki z domu, brak więzi z rodziną oraz uzależnienie rodziców (Raport: Problem handlu dziećmi w Polsce 2010). W tych wszystkich sytuacjach sprawca może dostrzec drogę dojścia do dziecka, które pozbawione jest uwagi rodziców. Wszelkie inne dysfunkcje rodziny będą oddalały dziecko od rodziców, a tym samym zbliżały je do popadnięcia w niebezpieczne sytuacje oraz powodowały łatwość zaufania innym osobom.

Dzieci stanowią grupę, która jest bardziej podatna na manipulację. Ze względu na mniej doświadczeń życiowych oraz nieznajomość niektórych problemów społecznych są one bardziej łatwowierne. Poczucie osamotnienia może powodować, iż bez krytyki podejdą one do propozycji niektórych osób, nieprawidłowo je ocenią i podejmą błędne decyzje. Poprzez to mogą stać się one przedmiotem transakcji, które naruszają ich prawa (Kociucki 1999).

W artykule 114 i kolejnych Kodeksu rodzinnego i opiekuńczego wymienione zostało przysposobienie, czyli adopcja dziecka. Są tu określone warunki, które musi spełniać 
osoba, chcąca adoptować małoletniego. Głównym celem tej procedury jest dobro dziecka. Natomiast osoba przysposabiająca musi wywiązywać się ze swoich obowiązków związanych $z$ adopcją, posiadać opinię kwalifikacyjną, a także świadect wo ukończenia szkolenia zorganizowanego przez ośrodek adopcyjny (Ustawa z dnia 25 lutego 1964 r., Dz. U. 1964, nr 9 poz. 59, Kodeks rodzinny i opiekuńczy). W odniesieniu do tego kodeksu handlem ludźmi będzie np. nielegalne szukanie przyszłych rodziców oraz dzieci do adopcji, pozyskiwanie zgody rodziców naturalnych, dokonywanie czynności mających na celu uzyskanie orzeczenia sądowego oraz załatwianie wszelkich innych i niezbędnych formalności (Góral 1998). Po etapach działania handlarzy w krajach pochodzenia ofiary zostają przewożone przez kraje tranzytowe, a w kraju docelowym czeka już na nie konkretny nabywca.

Ważnym aktem prawnym jest również Protokót fakultatywny do Konwencji o prawach dziecka w sprawie handlu dziećmi, dziecięcej prostytucji i dziecięcej pornografii $z$ dnia 27 kwietnia 2007 r., w którym szczególną uwagę zwraca się na problem dziecięcej prosty tucji oraz pornografii. Szczególnie narażoną grupę ryzyka stanowią w tym kontekście małe dziewczynki wykorzystywane seksualnie. W internecie udostępnianych zostaje wiele zdjęć z wizerunkiem półnagich dziewczynek, a same przyczyny wykorzystywania dzieci są różnorodne: ubóstwo, niedorozwój, dysfunkcja rodziny, migracja, brak wykształcenia, dyskryminacja płciowa itd. (Protokól fakultatywny do Konwencji o prawach dziecka w sprawie handlu dziećmi, dziecięcej prostytucji i dziecięcej pornografii, przyjęty w Nowym Jorku dnia 25 maja 2000 r., Dz. U. z dnia 27 kwietnia 2007 r.).

Różnorodność form handlu dziećmi zmienia się ze względu na podatność klientów na „rynku podaży dzieci”. Stąd jedną z nowoczesnych, a zarazem brutalnych form handlu dziećmi, jest handel ich organami, a tu szczególnie w celach rytuałów voodoo czy praktyk satanistycznych (Morawska 2006).

Trudno jest rozpoznać dzieci, które są ofiarami handlu ludźmi. Przede wszystkim takie dzieci - młodsze czy w wieku nieco starszym, często uważane są za nielegalnych imigrantów, włóczęgów czy nawet przestępców (Lööf 2005). Również świadomość społeczeństwa pod tym względem jest niewystarczająca. Widząc żebrzące kobiety w tramwajach, autobusach miejskich, trudno jest sobie wyobrazić, że dziecko, które żebrze razem z matką, może być taką ofiarą. Odtrąca się takie osoby, ponieważ często narzucają się one z żebractwem, a w takich przypadkach środki, które uda się uzbierać ofiarom, są również przekazywane w znacznej części tym, którym podlegają.

\section{Handel ludźmi do pracy przymusowej}

Praca przymusowa, która zaliczana jest do aspektów handlu ludźmi, jest bez wątpienia formą niewolnictwa, czyli zjawiska społecznego, polegającego na tym, że „określona grupa ludzi jest własnością innych ludzi, którzy w pełni o nich decydują, rozporządzają nimi” (Słownik współczesnego języka polskiego 1996). Poszerzaniu się zjawiska pracy przymusowej niewątpliwie sprzyja imigracja zarobkowa. Problem migrantów w Polsce pojawił się po 1989 roku, czyli po zmianach systemowych. Otwarcie granic na początku lat 90. skutkowało wzmożonym ruchem ludności. Krajami, z których imigrowano do Polski były: Ukraina, Białoruś, Rosja, Litwa, Bułgaria czy Rumunia. W Polsce jest zdecydowanie więcej migrantów przebywających nielegalnie. Liczbę nielegalnie przebywających Ukraińców w Polsce szacuje się na poziomie od 300000 do 500000 , lecz wydanych zostało tylko 3000 
pozwoleń na pracę. Natomiast liczba Wietnamczyków w Polsce wynosi od 50 ooo do 60 ooo, podczas gdy liczba wiz wydawanych rocznie dla tych obywateli wynosi od 500 do 7000 (Lasocik, Wieczorek 2010).

W art. 24 Konstytucji Rzeczypospolitej Polskiej z dnia 2 kwietnia 1997 r. mieści się przepis, w którym znajduje się zapis, iż „praca znajduje się pod ochroną Rzeczypospolitej Polskiej. Państwo sprawuje nadzór nad warunkami wykonywania pracy" (Konstytucja Rzeczypospolitej Polskiej z dnia 2 kwietnia 1997 r.). W myśl tego artykułu nie można nikomu narzucać wyboru zawodu lub pracy. Zatem Konstytucja wprowadza zakaz pracy obowiązkowej lub przymusowej (Banaszak 2009). Również polski Kodeks karny w art. 115, par. 22 definiuje, że praca o charakterze przymusowym jest formą handlu ludźmi (Ustawa $z$ dnia 6 czerwca 1997 r., Dz. U. z 1997 r.. nr 168, poz. 1323, Kodeks karny 2007, 2014).

Najczęściej ofiary pracy przymusowej zmuszane są do pracy na plantacjach rolnych, podczas której zbierają warzywa lub owoce. Warunki pracy dla takich ludzi w rzeczywistości są zupełnie inne niż zakładały początkowe obietnice czy umowy. W tej sytuacji nie zgadza się nie tylko wynagrodzenie, ale również rodzaj pracy. Np. Ukraińcom bardzo często proponuje się pracę $\mathrm{w}$ charakterze opieki domowej lub na bazarach, podczas gdy w rzeczywistości jest to żebractwo. Ofiary zazwyczaj nie otrzymują również żadnego wynagrodzenia za swoją pracę, z wyjątkiem środków na podstawowe wyżywienie. Sprawca tak manipuluje ofiarą, że na początku wmawia jej, iż całościowe wynagrodzenie za pracę przeznaczone jest na opłacenie jej pobytu w danym państwie, a następnie zmusza ją do podpisania dokumentów, iż otrzymała ona wynagrodzenie za pracę. W niektórych częściach świata istnieją specjalnie wyznaczone przez przestępców międzynarodowych obozy pracy. W takich miejscach ofiary pracują nawet do 15 godzin dziennie, niekiedy po 7 dni. Ofiary handlu ludźmi, w tym przypadku pracy przymusowej, mają silne przeświadczenie, że muszą spłacić dług względem sprawców (Lasocik, Wieczorek 2010).

\section{Współczesne wymiary handlu ludźmi}

\section{Prezentacja typowych przypadków}

Poniżej przedstawione zostały autentyczne sytuacje dotyczące handlu ludźmi.

Handel dziećmi:

„Grupa białoruskich dzieci uprowadzonych przez grupę młodych ludzi, podających się za ich opiekunów prawnych, przemierzyła 5 krajów europejskich. W krajach tych handlarze znajdowali klientów - dzieci były tam zmuszane do uprawiania prostytucji. Najmłodsze dzieci żebrały, aby dostać coś do jedzenia, starsze opiekunowie zmuszali do kradzieży. $\mathrm{W}$ jednym $\mathrm{z}$ krajów europejskich dzieci zatrzymano, udzielono im pomocy. Ich opiekunowie uciekli. W trakcie śledztwa okazało się, że zdjęcia i filmy pornograficzne z udziałem dzieci oferowano w Internecie" (Problem handlu dziećmi w Polsce i na świecie 2008).

Handel kobietami:

Jedną z ofiar handlu kobietami jest Joanna. Ma 25 lat. [...] studiowała prawo. [...] Gdy dostała się na drugi rok, rozwiedli się jej rodzice. Musiała szukać pracy. - Koleżanka zaproponowała, żebyśmy wyjechały jako hostessy do Japonii. Niby wszystko było już nagrane, praca załatwiona, na lotnisku w Tokio miał czekać jakiś jej znajomy. Ale 
nie wyszło. Nie wpuścili nas. Wtedy nie wiedziałam, że po prostu dwóch młodych kobiet nie wpuszczą, taki mają problem z europejskimi prostytutkami. Joanna załamała się. Po nocy spędzonej w japońskim hotelu na lotnisku wróciła $\mathrm{z}$ koleżanką do Polski. - Miałam dług. Zapożyczyłam się u znajomych na ponad trzy tysiące, za które kupiłam bilet do Japonii. Musiałam szybko zdobyć pieniądze - opowiada. Wtedy natknęła się na ogłoszenie. „Dobrze płatna praca w nocnych klubach we Włoszech. Nie wiem, czy byłam taka naiwna, czy chciałam wierzyć, że naprawdę będę kelnerką - mówi gorzko" (Łagowska 2006).

\section{Praca przymusowa:}

Kobietom obiecano dużo: miesięczną pensję w wysokości 560 dolarów, darmowe mieszkanie, wyżywienie i opiekę medyczną. Zamiast tego kobiety trafiły do polskiego obozu pracy. Kiedy pojawiła się możliwość pracy w Polsce za godziwe pieniądze, Filipinki niedługo się wahały. Zadłużyły się na podróż i w połowie września przyjechały do Parczewa koło Lublina. Jeszcze na Filipinach kobiety podpisały umowę o pracę z polską agencją. Kobietom obiecano godziwe warunki: 560 dolarów za ośmiogodzinną pracę pięć razy w tygodniu. [...] Niektóre dziewczyny, żeby tu przyjechać, zastawiły swoje mieszkania w bankach. [...] Obiecane pieniądze miały zarobić przy zbieraniu pieczarek. [...] Jednak po przyjeździe kobiety otrzymały do podpisania kolejny dokument. [...] Kiedy poprosiłyśmy o tłumacza, powiedział, że to jest ta sama umowa, którą podpisałyśmy na Filipinach. [...] Okazało się, że to nie była ta sama umowa. Kobietom podsunięto umowę o dzieło, w której zapisane było, że będą pracować na akord i dostawać 35-55 groszy za zebrany kilogram pieczarek. O reszcie świadczeń nie było już mowy. [...] Dla Filipinek zaczął się trudny czas. Mieszkały na terenie zakładu w wieloosobowych salach. Grzyby zbierały w pieczarkarni oddalonej o kilkadziesiąt kilometrów. - Wstawałyśmy o godzinie 4 rano. Wyjeżdżałyśmy autobusem o godzinie 6. Pracę zaczynałyśmy godzinę później. Z zakładu wyjeżdżałyśmy o 20-21 czasami o 22. Do Parczewa przyjeżdżałyśmy około północy (Prosiłam, żeby przestali traktować nas jak niewolników 2009).

Na podstawie powyższych przykładów można zauważyć wiele błędów ofiar przestępstwa handlu ludźmi. Przede wszystkim u podstaw leży naiwność kobiet. Zła sytuacja finansowa rodziny powoduje, iż naprawdę wierzą one w poprawienie swojego bytu w taki sposób. Wydawałoby się również, że gdy kobieta decyduje się wyjechać do innego państwa w celach zarobkowych ze znajomą lub do osoby poleconej jej przez znajomą, to wyjazd ten wydaje się być bezpieczniejszy i bardziej prawdopodobny. Niestety, jak widać na podstawie powyższych przykładów, osoby wykształcone również są łatwowierne i stają się ofiarami handlu ludźmi. Gdy sprawca proponuje ofierze wiele korzyści z pracy, to trudno jest myśleć w sposób obiektywny, ponieważ w pierwszej olejności liczy się chęć poprawy sytuacji finansowej rodziny. Jakże brutalne musi być to doświadczenie szczególnie dla tych ofiar, które we własnym domu doświadczały różnego rodzaju patologii związanych z przemocą, a w przestępstwie handlu ludźmi doznały kolejnego poniżenia.Jeśli natomiast mamy na uwadze handel dziećmi, to jakże tragiczne mają one dzieciństwo, gdy już od najmłodszych lat muszą pracować na własne utrzymanie. Niekiedy, gdy żebrzą wraz z matką, można 
zauważyć na ich twarzy przemęczenie czy brak sensu życia. Świadczy to tylko o tym, że nie mają one dalszych, lepszych perspektyw, nie mogą funkcjonować jak ich rówieśnicy bawić się i być chronione przez własną rodzinę. W innych przypadkach są one specjalnie sprzedawane przez biologiczne matki, które potrzebują środków finansowych. Należy tu zauważyć, że sprzedawane są nie tylko w celach adopcji, ale również w takich przypadkach, gdy matka dobrze wie, iż dziecko stanie się ofiarą handlu ludźmi. Żebractwo dzieci powoduje codzienne, rytualne czynności - przymusową pracę. Gdy dochodzi do tego prostytucja dziecięca, tak młode osoby pozbawiane są własnej godności.

Ściganie przestępstwa handlu ludźmi - aspekty prawne zwalczania problemu, sytuacja ofiary

W polskim prawie dotyczącym handlu ludźmi występuje wiele aktów mówiących o ochronie osób, co do których jest podejrzenie, iż mogą być one ofiarami tego przestępstwa. Ustawa o cudzoziemcach $z$ dnia 13 czerwca $2003 \mathrm{r}$. w art. 53, ustępie 15, zezwala na pobyt na czas określony cudzoziemcowi, który jest ofiarą handlu ludźmi, ale musi on podjąć współpracę z właściwym organem ścigania i zerwać wszelkie stosunki z osobami podejrzanymi o handel ludźmi. Co do zasady pobyt ten wynosi 3 miesiące, jednak nie może on być dłuższy niż 2 lata (Ustawa $z$ dnia 13 czerwca 2003 r. o cudzoziemcach, Dz. U. 2003, nr 128, poz. 1175). Ochronę tę zapewnia również Ustawa o udzielaniu cudzoziemcom ochrony na terytorium Rzeczypospolitej Polskiej (Dz. U. 2003, nr 128, poz. 1176., Kodeks karny 2007).

Artykuł 189a. polskiego Kodeksu karnego zawiera w sobie treść, zgodnie z którą

Kto dopuszcza się handlu ludźmi, podlega karze pozbawienia wolności na czas nie krótszy niż 3 lata. $\$ 2$. Kto czyni przygotowania do popełnienia przestępstwa określonego $\mathrm{w} \$ 1$, podlega karze pozbawienia wolności od 3 miesięcy do lat 5 " (Ustawa z dnia 6 czerwca 1997 r., Dz. U. z 1997 r.,, nr 168, poz. 1323, Kodeks karny 2007, 2014). Na podstawie tego przepisu także poczynanie przygotowań w związku z przestępstwem handlu ludźmi podlega odpowiedzialności karnej. Natomiast $\$ 22$ art. 115 kodeksu określa czynności handlu ludźmi, jakimi są: „werbowanie, transport, dostarczanie, przekazywanie, przechowywanie lub przyjmowanie osoby z zastosowaniem: 1) przemocy lub groźby bezprawnej, 2) uprowadzenia, 3) podstępu, 4) wprowadzenia w błąd albo wyzyskania błędu lub niezdolności do należytego pojmowania przedsiębranego działania, 5) nadużycia stosunku zależności, wykorzystania krytycznego położenia lub stanu bezradności, 6) udzielenia albo przyjęcia korzyści majątkowej lub osobistej albo jej obietnicy osobie sprawującej opiekę lub nadzór nad inną osobą" (Ustawa z dnia 6 czerwca 1997 r., Kodeks karny 2007, 2014). Inny przypadek handlu ludźmi, jakim jest nielegalna adopcja przedstawiony został w art. 211a. Kodeksu: „ Kto, w celu osiągnięcia korzyści majątkowej, zajmuje się organizowaniem adopcji dzieci wbrew przepisom ustawy, podlega karze pozbawienia wolności od 3 miesięcy do lat 5 (Ustawa $z$ dnia 6 czerwca 1997 r.).

W międzynarodowych działaniach przeciwko handlowi ludźmi, przyjętych przez Organizację Narodów Zjednoczonych wymienić można następujące akty prawne dotyczące tego zjawiska: Konwencja w sprawie zwalczania handlu ludźmi i eksploatacji prostytucji, 
ratyfikowana przez Polskę w 1952 roku; Konwencja w sprawie eliminacji wszelkich form dyskryminacji kobiet, ratyfikowana przez Polskę w 1952 roku; Protokół o zapobieganiu, zwalczaniu oraz karaniu handlu ludźmi, w szczególności kobietami i dziećmi (protokół dodatkowy do Konwencji Narodów Zjednoczonych przeciwko międzynarodowej przestępczości zorganizowanej). Rada Europy zapobiega handlowi ludźmi na podstawie w Konwencji o Ochronie Praw Człowieka i Podstawowych Wolności; Zalecenia nr R. (200o) 11 Komitetu Ministrów „w sprawie działania przeciwko handlowi ludźmi w celu seksualnego wykorzystywania; Zalecenia 1545 (2002) w sprawie kampanii przeciwko handlowi kobietami. Na obszarze Unii Europejskiej Rada Europy zorganizowała w 1996 r. utworzenie programu Stop, mającego na celu szkolenia dla ekspertów i organizacji pozarządowych zwalczających handel ludźmi. W roku 1997 program ten został uzupełniony poprzez inicjatywę Daphne, zwalczającą przemoc wobec kobiet. W 1998 roku do Załącznika Konwencji o Europolu została uzupełniona definicja pojęcia handlu ludźmi. W roku 1999 Traktat Amsterdamski wprowadził gwarancję w zapobieganiu przestępczości zorganizowanej, zaś w roku 2000 w Karcie Praw Podstawowych uwzględniony został zakaz pracy przymusowej oraz niewolnictwa. Następnie, w 2001 roku, programem Stop II objęto wybrane kraje trzecie. W 2002 roku w Decyzji Ramowej Rady z dnia 19 lipca 2002 r. w sprawie zwalczania handlu ludźmi ustalono, że indywidualnym państwom może być trudno zwalczać problem handlu ludźmi, zatem ważne jest podejście ogólnoeuropejskie. Rok później powstała Decyzja Ramowa Rady Unii Europejskiej, która uwzględniła w sposób szczególny wykorzystywanie seksualne dzieci oraz dziecięcej pornografii. W roku 2003 powstał program Agis obejmujący współpracę różnych organów ścigania przestępstwa handlu ludźmi w zakresie międzynarodowym (Dawid-Olczyk, Dośpiał 2004).

Na podstawie Dyrektywy Parlamentu Europejskiego i Rady z dnia 5 kwietnia 2011 r. $w$ sprawie zapobiegania handlowi ludźmi i zwalczania tego procederu oraz ochrony ofiar, istnieją tzw. okoliczności wyłączające czyn ofiary, np. w momencie, gdy jest ona w stanie silnego pobudzenia (szoku) lub też głębokiego przerażenia. W sytuacji prawnej ofiary bierze się pod uwagę również ochronę jej życia, zdrowia i wolności czy też obronę konieczną. Gdy uwięziona ofiara w zamiarze ucieczki rani ochroniarza, także zostaje wyłączona z odpowiedzialności. Skutek naiwności ofiary, poprzez co wzięła ona udział w handlu ludźmi też jest przesłanką do wyłączenia jej bezprawności. Osoby trzecie mogą pomagać ofiarom handlu ludźmi, naruszając określone dobro w celu uwolnienia ich z rąk sprawców. Okoliczność wyłączającą winę ofiary stanowi jej wiek, a więc np. nieletniość, przy czym należy pamiętać, że w prawie karnym granicą odpowiedzialności karnej nieletnich jest 17 roku życia, zaś w wyjątkach jest to nawet 15 rok życia. Wyłączenie winy zezwalane jest również ze względu na niepoczytalność ofiary. Przede wszystkim najważniejszą przesłanką odstąpienia od kary dla ofiar handlu ludźmi jest udział w czynie, do którego zostały one zmuszone (w formie fizycznej lub psychicznej). Ponadto Dyrektywa uwzględnia szczególna ochronę ofiar, która ma zapobiec dalszej ich wiktymizacji (Sitarz 2013).

Praca psychologiczno-pedagogiczna z ofiarami handlu ludźmi

Mając na uwadze ofiary handlu ludźmi, należy zaoferować im odpowiednią pomoc psychologiczno-pedagogiczną. W tym celu swą działalność prowadzą organizacje pozarządowe zajmujące się ściśle tym zjawiskiem. 
W pierwszej kolejności ważne jest posiadanie wiedzy przez ofiary o tym, że istnieją odpowiednie instytucje i organizacje zwalczające problem handlu ludźmi. Bardzo istotną kwestią jest posiadanie przez osoby wyjeżdżające za granice kraju kontaktu do Konsulatu RP, który ma obowiązek wszcząć dalsze procedury. Następnie, gdy ofiara zdecyduje się na przyjęcie pomocy od dalszych instytucji, może ona uzyskać odpowiednie wsparcie psychologiczne.

Jedną z fundacji, oferujących pomoc kobietom - ofiarom handlu ludźmi jest La Strada, powstała w 1996 r. Fundacja ta posiada telefon zaufania, pod który mogą dzwonić ofiary handlu ludźmi, jak również osoby, które zauważyły w swoim otoczeniu niepokojące sytuacje, być może powiązane z tym przestępstwem. Organizacja wydaje poradniki, przeznaczone dla kobiet wyjeżdżających za granicę, a także prowadzi różnorodne programy i kampanie, informujące o problemie handlu ludźmi i nagłaśniające go. Swą pomoc oferuje ona także autentycznym ofiarom handlu. Takie osoby mogą liczyć m.in. na schronienie, porady prawne, pomoc medyczną i psychologiczną czy zaspokojenie podstawowych potrzeb. Innymi formami pomocy jest praca nad reintegracją społeczną ofiar. Dzięki działalności fundacji poszkodowane kobiety mogą liczyć na konsultacje indywidualne z psychologami i terapeutami, jak również uczestniczyć w programach, tworzonych przez tę organizację, mających na celu przepracowywanie doznanych krzywd. Fundacja oferuje także interwencję kryzysową, w ramach której możliwe są mediacje rodzinne dla ofiar handlu. Również w momencie składania zeznań przez ofiarę, otrzymuje ona wsparcie prawne i psychologiczne. Fundacja prowadzi również psychoterapię oraz wspiera w poszukiwaniu pracy przez ofiary (Kampania „Modelki mówią STOP!”).

Inną organizacją pomocową jest Fundacja Pomocy Ludziom Dotkniętym Problemem Zaginięcia Itaka. Przede wszystkim prowadzi ona akcje profilaktyczne, dzięki którym możliwe jest zapobieganie zagranicznym zaginięciom osób dorosłych oraz zapobieganie uprowadzaniu dzieci czy porwaniom rodzicielskim. Także ofiary handlu ludźmi mogą skorzystać $\mathrm{z}$ telefonu zaufania $\mathrm{w}$ celu uzyskania informacji na temat działania, jak również rozmowy z psychologiem o danym problemie ofiary. Także rodziny, które znajdują się w złej sytuacji materialnej, mogą liczyć na wsparcie i pomoc socjalną oraz prawną (Jak ITAKA może pomóc).

Praca pedagogiczna w zakresie zapobiegania handlu ludźmi odbywa się poprzez edukację młodzieży w szkołach, w których uczestniczy ona w zajęciach przygotowanych przez pedagoga lub zespół innych specjalistów. Istotne jest, by pobudzić myślenie w zakresie tego, jak łatwo można stać się ofiarą i jak wiele niebezpieczeństw może czekać na człowieka, gdy postanawia on oddalić się od swoich bliskich, np. w celu zdobycia lepszej pracy. Podczas przekazu teoretycznego powinny być udostępniane informacje o instytucjach pomocowych oraz powinno się i uświadamiać, że ważne jest posiadanie takich adresów, gdy przebywa się na terytorium innego kraju.

Osoby, które padły ofiarami przestępstwa handlu ludźmi, przede wszystkim zapewnione mają wsparcie psychologiczne. Bardzo często są to jednostki, które zostały okłamane poprzez swoją naiwność. Gdy odkryją one, że ich agresorami są mężczyźni, wcześniej oferujący im wymarzoną miłość, przeżywają one kolejne rozczarowanie i zawody. Jeśli wobec nich stosowana była przemoc fizyczna, a w szczególności jej dotkliwe przejawy, tj. pobicia, a nawet zmuszanie do prostytucji, to kobiety te mogą przejawiać skłonności samobójcze, zarzucać sobie, że w odpowiednim czasie nie potrafiły rozpoznać danego 
problemu. Ważna jest tu praca, pozwalająca na przepracowanie zachowań lękowych, a także wskazująca na inne sfery funkcjonowania jednostki, dzięki którym stopniowo będzie mogła ona wrócić do sytuacji sprzed zajścia przestępstwa. Istotne jest również wskazanie rodzinie ofiary tego, iż powinna czuć płynące od nich ciepło emocjonalne i wsparcie, by nie czuła się osamotniona.

Wobec ofiary ważne jest podjęcie planu jej reintegracji. Powinien on zawierać w sobie kilka najważniejszych części dotyczących pomocy ofierze. Są to m.in.: połączenie ofiary z jej rodziną, rehabilitacja zdrowotna, przekazanie jej środków materialnych na nowy start, zapewnienie pomocy prawnej, oferowanie przyuczenia do zawodu czy też szkoleń zawodowych, zorganizowanie pola zarobkowego oraz zapewnienie odpowiedniego bezpieczeństwa. Wsparcie to może odbywać się w krótkim odcinku czasu (zorganizowanie powrotu do kraju, badań medycznych, zakwaterowania i pomocy prawnej). Może ono również trwać dłużej, w sytuacji, gdy ofierze trudno jest przystosować się do społeczeństwa - wtedy monitoruje się proces jej reintegracji (Podręcznik IOM 2007).

\section{Podsumowanie}

Istnieje wiele form handlu ludźmi. Przestępstwo to, tak jak inne zjawiska, rozwija się coraz bardziej, a wśród społeczeństwa może brakować wiedzy na ten temat, by odpowiednio rozpoznawać problem. Różnego rodzaju instytucje i organizacje pozarządowe zajmujące się przeciwdziałaniu handlu ludźmi oraz wsparciem ofiar nie posiadają dokładnych statystyk na ten temat.

Potencjalnej ofierze handlu ludźmi trudno jest przewidzieć, jakie niebezpieczeństwo może czekać na nią za granicą, zwłaszcza, gdy jest skoncentrowana na celu zarobkowym. Wśród ofiar duży odsetek stanowią kobiety oraz dzieci - w tym nawet osoby o wysokim poziomie wykształcenia.

Szczególnie dramatyczny jest los dzieci, które celowo sprzedawane są z rąk swoich rodziców w celach wykorzystania seksualnego lub też specjalnie wyszukiwane przez osoby, składające na nie zamówienia. Nieludzkie jest również zmuszanie ofiar do ciężkiej pracy, wynagradzanej często tylko podstawowym wyżywieniem jednostki.

Skomplikowana i trudna jest tu sytuacja ofiary, która jako słabsza strona przestępstwa obawia się składania zeznań.

Sytuacja materialna i chęć poprawy stopy życiowej czy czasami zwykła zmiana otoczenia (emigracja do innego kraju) mogą być przesłankami, poprzez które jednostka decyduje się na oddalenie od swoich bliskich, co może spowodować zaistnienie niebezpiecznej dla zdrowia, życia i wolności sytuacji. Po zaistnieniu przestępstwa znacząca rolę odgrywają służby, które przyjmują zgłoszenie o handlu ludźmi i powinny wiedzieć, gdzie należy pokierować taką ofiarę, co powinna dalej zrobić i jak jej pomóc. Zwalczanie tego trudnego przestępstwa powinno być dokonywane w taki sposób, by podczas wszelkich przesłuchań ofiara miała poczucie bycia chronioną, nie zaś była atakowana i straszona sankcjami, które grożą jej za nielegalną pracę, postrzegana jako przestępca.

W aspekcie społecznym należy budować coraz większą świadomość oraz informować społeczeństwo o zjawisku handlu ludźmi, również poprzez przekaz medialny. Chociaż pod względem prawnym istnieje wiele przepisów, które odnoszą się do zapobiegania i zwalczania handlu ludźmi, a przestępstwo to uważane jest za międzynarodowe i poszczególne 
kraje łączą się, by wspólnie je zwalczać, to nadal trudno jest ścigać grupy przestępcze zajmujące się nim.

\section{Bibliografia}

Banaszak B. (2009). Konstytucja Rzeczypospolitej Polskiej. Komentarz. Warszawa: Wydawnictwo C. H. Beck.

Deklaracja ONZ o podstawowych zasadach sprawiedliwości dla ofiar przestępstw i nadużyć władzy, dostępny na: http://www.swidnica.po.gov.pl/prawe_menu/ofiara_karta_tresc. html (otwarty 01.07.2014).

Encyklopedia popularna PWN. (1982). Łąkowski Ł. (red.). Warszawa: PWN.

Góral R. (1998). Kodeks karny. Praktyczny komentarz. Warszawa: Wydawnictwo Zrzeszenia Prawników Polskich. Jak ITAKA może pomóc, dostępny na: http://zaginieni.pl/jak-itaka-moze-pomoc (otwarty 27.12.2014).

Kalina-Prasznic U. (2004). Encyklopedia prawa. Warszawa: Wydawnictwo C. H. Beck.

Kampania „Modelki mówią STOP!”, dostępny na: http://www.strada.org.pl/index.php/pl/ la-strada-w-dzialaniu/dzialania, (otwarty 28.11.2014).

Kangaspunta K., Sarrica F., Johansen R., Chatzis I., Taveau A., Kunnen S. , Kuttnig K. (2012). Global Report on trafficking in persons 2012. New York: United Nations Office on Drugs and Crime.

Karsznicki K. (2010). Ściganie przestępstwa handlu ludźmi w Polsce. Warszawa: Uniwersytet Warszawski, Ośrodek Badań Handlu Ludźmi.

Kociucki L. (1999). Zwalczanie nielegalnego transferu dzieci. W: Smyczyński T. (red.). Konwencja o prawach dziecka. Analiza i wykładnia. Wydawnictwo Ars Boni et aequi.

Konstytucja Rzeczypospolitej Polskiej z dnia 2 kwietnia 1997 r. Kancelaria Sejmu, dostępny na: http://isap.sejm.gov.pl/DetailsServlet?id=WDU19970780483.

Konwencja o prawach dziecka przyjęta przez Zgromadzenie Ogólne Narodów Zjednoczonych dnia 20 listopada 1989 r., dostępny na: http://isap.sejm.gov.pl/DetailsServlet?id= WDU19911200526.

Lasocik Z., Wieczorek Ł. (red.). (2010). Handel ludźmi do pracy przymusowej w Polsce raport z badań. Warszawa: Uniwersytet Warszawski. Ośrodek Badań Handlu Ludźmi.

Lööf L. (2005). Dzieci i młodzież - ofiary handlu. Działania regionalne na rzecz zapewnienia im prawa do ochrony, opieki i rehabilitacji. „Dziecko krzywdzone”, nr 3.

Łagowska K., Kupię kobiete, sprzedam kobietę, „Gazeta Wyborcza”, Wrocław dodatek „Wieża Ciśnień”, nr 116, 19.05.2006.

Morawska A. (2007). Handel dziećmi w perspektywie europejskiej - wyzwania dla praktyków. W: Lasocik Z., Koss M., Wieczorek Ł. (red.). Handel dziećmi. Wybrane problemy. Warszawa: Uniwersytet Warszawski. Ośrodek Badań Handlu Ludźmi.

Morawska A. (2006). Handel dziećmi - zarys zjawiska, W: Lasocik Z. (red.). Handel ludźmi. Zapobieganie i ściganie. Warszawa: Uniwersytet Warszawski. Ośrodek Badań Handlu Ludźmi.

Hasło: niewolnictwo. Dunaj B. (red.). (1996). Słownik współczesnego języka polskiego. Warszawa: Wydawnictwo WILGA.

Państwo Islamskie opublikowało cennik niewolnic. 580 zł za 9-letnia chrześcijankę, 15ozł za 5o-latkę, dostępny na: http://wiadomosci.wp.pl/kat,139954,opage, 
9,title,Panstwo-Islamskie-opublikowalo-cennik-niewolnic-58o-zl-za-9-letnia-chrzescijanke-15ozl-za-50-latke,wid,17018652,wiadomosc.html?ticaid=113df6 (otwarty 26.10.2014). Podręcznik IOM. Bezpośrednia pomoc ofiarom handlu ludźmi (2007). Genewa: Międzynarodowa Organizacja do spraw Migracji.

Problem handlu dziećmi w Polsce i na świecie. (2008). Fundacja Dzieci Niczyje, dostępne na: http://www.canee.net/files/The\%2oproblem\%20of\%20child\%2otrafficking\%2oin\%20 Poland\%20and\%2oin\%2othe\%2oworld.pdf (otwarty 26.11.2014).

Prosiłam, żeby przestali traktować nas jak niewolników. (2009), dostępny na: http://www. tvn24.pl/wiadomosci-z-kraju,3/prosilam-zeby-przestali-traktowac-nas-jak-niewolnikow,210910.html (otwarty 28.11.2014).

Protokół fakultatywny do Konwencji o prawach dziecka $w$ sprawie handlu dziećmi, dziecięcej prostytucji i dziecięcej pornografii, Dz. U. z dnia 27 kwietnia 2007 r., dostępny na: http://prawo.legeo.pl/prawo/protokol-fakultatywny-do-konwencji-o-prawach-dziecka-w-sprawie-handlu-dziecmi-dzieciecej-prostytucji-i-dzieciecej-pornografii-przyjety-w-nowym-jorku-dnia-25-maja-200o-r/.

Protokół o zapobieganiu, zwalczaniu oraz karaniu za handel ludźmi, w szczególności kobietami i dziećmi, uzupetniajacy Konwencję Narodów Zjednoczonych przeciwko międzynarodowej przestępczości zorganizowanej z dnia 15 listopada 2000 r., dostępny na: http://isap.sejm.gov.pl/DetailsServlet?id=WDU20050180158.

Raport: Problem handlu dziećmi w Polsce - opinie i doświadczenia profesjonalistów. (2010). Warszawa: Fundacja Dzieci Niczyje.

Sitarz O. (2013). O niekaralności ofiar handlu ludźmi - czyli polskie prawo karne materialne wobec zobowiąania wynikającego z art. 8 Dyrektywy Parlamentu Europejskiego i Rady $\mathrm{z}$ dnia 5 kwietnia $2011 \mathrm{r}$. w sprawie zapobiegania handlowi ludźmi i zwalczania tego procederu oraz ochrony ofiar. W: Lasocik Z. (red.). Niekaralność ofiar handlu ludźmi - wstępna diagnoza problemu. Warszawa: Uniwersytet Warszawski: Ośrodek Badań Handlu Ludźmi.

Sitarz O. (2007). Problem implementacji przepisów prawa międzynarodowego dotyczacych handlu dziećmi. W: Lasocik Z., Koss M., Wieczorek Ł. (red.). Handel dziećmi. Wybrane problemy. Warszawa: Uniwersytet Warszawski. Ośrodek Badań Handlu Ludźmi.

Sobczyk M., Przybysławska K. (2013). Raport: Zjawisko handlu ludźmi, w odniesieniu do cudzoziemców przebywających w Polsce za rok 2011 i 2012. Kraków: Centrum Pomocy Prawnej im. Haliny Nieć.

Ustawa z dnia 6 czerwca 1997. Dz. U. z 1997 r., nr 168, poz. 1323. W: Kodeks karny (2007, 2014). Ustawa $z$ dnia 25 lutego 1964 r, Dz. U. 1964, nr 9, poz. 59. W: Kodeks rodzinny i opiekuńczy. Ustawa $z$ dnia 13 czerwca 2003 r. o cudzoziemcach, Dz. U. 2003, nr 128, poz. 1175, dostępny na: http://isap.sejm.gov.pl/DetailsServlet?id=WDU20031281175.

Ustawa $z$ dnia 13 czerwca 2003 r. o udzielaniu cudzoziemcom ochrony na terytorium Rzeczypospolitej Polskiej, Dz. U. 2003, nr 128, poz. 1176, dostępny na: http://isap.sejm. gov.pl/DetailsServlet?id=WDU20031281176.

Wiśniewski, M. (2007). Handel ludźmi - statystyka. W: Handel ludźmi w Polsce. Materiały do raportu. Warszawa: Ministerstwo Spraw Wewnętrznych i Administracji. Zespół do Spraw Handlu Ludźmi. 


\title{
HUMAN TRAFFICKING - PROFILE AND SCALE OF THE PHENOMENON
}

\begin{abstract}
The article presents the basic issues of human trafficking. It is characterized by the victims of this crime (children and women), methods of operation of the perpetrators, the scale of the phenomenon and legal aspects of the fight against this problem. Information about cases of human trafficking is also included.
\end{abstract}

Key words: human trafficking, forced labor, child trafficking, victim, crime

Ewelina Ligęza - studentka drugiego roku pedagogiki na studiach drugiego stopnia na Wydziale Nauk Pedagogicznych Uniwersytetu Kardynała Stefana Wyszyńskiego w Warszawie. Adres e-mail: ligeza.e@gmail.com 